\title{
Rancang Bangun Sistem Pencampur Minuman Jamu Otomatis Berbasis Mikrokontroler
}

\author{
Nurul Fatimah ${ }^{1}$, Ratna Aisuwarya ${ }^{2}$ \\ 12 Jurusan Sistem Komputer FTI Universitas Andalas, Limau Manis, Padang 25163 INDONESIA
}

\section{ARTICLE INFORMATION}

Received: January 22, 2019

Revised: March 20, 2019

Available online: March 29, 2019

KEYWORDS
jamu, microcontroller, arduino mega, LDR
sensor, keypad, water flow sensor
CORRESPONDENCE

Phone: +62 81364619171

E-mail: nurulfatimaah1@gmail.com

\section{A B S T R A C T}

People in general have a desire to live a healthy life. One way to keep health is by consuming herbal drinks, one of them is known as jamu. Jamu which is commonly found is "jamu gendong" which is a home-based herbal product that is marketed in the form of liquid in the bottle. When buying jamu, the seller will mix various types of jamu by pouring jamu from each bottle into a glass according to the buyer's request. However, mixing several types of jamu is carried out using the seller estimate, so the dosage of several types of jamu to the glass will vary according to the pouring. The purpose of this research is to make a arduino Mega based automatic jamu beverage mixing system. This system uses an LDR sensor to detect the presence of a glass with a resistance value read by an LDR sensor is $>500 \mathrm{ohm}$ and a DC motor can move by the stirrer. The selection of the jamu menu's is done by pressing the keypad button from the code ' 1 ' to the code ' 8 '. After the menu is selected, the jamu will flow to the glass and the volume of jamu will be calculated using a water flow sensor that uses multiplier values. For the volume of $150 \mathrm{~mL}$ is used to multiplie factor 3.7 , for the volume of $100 \mathrm{~mL}$ is used to multiplie factor 2.9 , and for the volume of $50 \mathrm{~mL}$ is used to multiplie factor 1.2 .

\section{PENDAHULUAN}

\section{Latar Belakang}

Masyarakat pada umumnya memiliki keinginan untuk hidup yang sehat dan bugar. Banyak cara yang dilakukan oleh masyarakat untuk menjaga kesehatannya dengan hal-hal yang sederhana dan mudah untuk dilakukan, salah satunya dengan mengkonsumsi minuman herbal. Minuman herbal berasal dari bahan alami yang bermanfaat bagi tubuh. Minuman herbal tersebut biasa dikenal dengan jamu.

Jamu merupakan obat hasil ramuan tumbuh-tumbuhan asli dari alam yang tidak menggunakan bahan kimia sebagai adiktif [1]. Jamu dapat ditemukan di toko obat dalam bentuk kemasan sachet dan bisa juga didapatkan dari penjual jamu gendong yang berkeliling dilingkungan sekitar. Jamu gendong merupakan produk jamu rumahan yang dipasarkan berupa cairan dalam bentuk botol-botol. Ada beberapa jenis jamu gendong yang biasa dipasarkan antara lain kunyit asam, beras kencur, pahitan, dan lain sebagainya.
Jamu gendong digemari masyarakat dikarenakan jamunya mudah untuk didapatkan yaitu dari penjual jamu yang menawarkan dagangannya kerumah-rumah, sehingga tidak perlu pergi jauh untuk membeli jamu. Dan jamu gendong dipilih karena jamu dibuat atau diolah setiap hari oleh penjual, sehingga menghasilkan jamu yang segar.

Pada saat membeli jamu gendong, penjual akan meracik atau mencampurkan berbagai jenis jamu dengan menuangkan jamu dari masing-masing botol ke gelas sesuai dengan permintaan pembeli. Namun penuangan dan pencampuran beberapa jenis jamu yang dilakukan oleh peracik hanya menggunakan perkiraan saja, sehingga takaran dari beberapa jenis jamu ke gelas akan berbeda-beda atau tidak konstan setiap penuangannya.

Ada beberapa penelitian sebelumnya terkait dengan pencampuran minuman. Pada penelitian tahun 2015 [2], dibuat alat pembuat kopi otomatis yang diimplementasikan menggunakan mikrokontroler ATMega8535. Sistem kendali ini dapat membuat beberapa variasi kopi dengan memperhitungkan akurasi volume air sehingga ketepatan ukuran dan rasanya ideal. Dari penelitian tersebut dapat dikembangkan suatu sistem pencampur minuman otomatis yang lebih spesifik khususnya pada jamu. 


\section{Tujuan Penelitian}

Tujuan yang ingin dicapai dari penelitian tugas akhir ini adalah :

1. Mengaktifkan sistem berdasarkan keberadaan gelas yang terdeteksi oleh sensor LDR.

2. Memberikan perintah kepada mikrokontroler untuk memproses permintaan user kepada jenis jamu yang tersedia sesuai inputan keypad.

3. Memberikan perintah kepada water flow sensor untuk menghitung debit jamu yang mengalir untuk menentukan volume jamu.

\section{Manfaat}

Manfaat dari penelitian tugas akhir ini adalah menghasilkan alat yang memudahkan pencampuran minuman jamu dari berbagai jenis jamu sesuai dengan takaran yang ditetapkan sehingga penuangan jamu ke gelas sesuai dengan takaran.

\section{LANDASAN TEORI}

\section{Jamu}

Jamu berasal dari kata djampi dan oesodo. Djampi berarti penyembuhan dengan menggunakan ramuan obat-obatan, doadoa, atau aji-aji, sedangkan oesodo berarti kesehatan. Jamu pada dasarnya merupakan obat tradisional, dimana ramuan atau bahan yang digunakan merupakan bahan herbal yang diracik sedemikian rupa dengan komposisi dan takaran tertentu hingga menjadi sebuah ramuan obat. Jamu memiliki khasiat untuk pencegahan atau preventif, perawatan atau promotif, pengobatan atau kuratif, dan pemulihan atau rehabilitatif. [1]

Adapun jenis dari jamu antara lain :

a. Beras Kencur

Ramuan dari campuran tepung beras dengan kencur yang ditumbuk dan diperas untuk diambil airnya. Jamu beras kencur berkhasiat untuk menghilangkan rasa kelelahan, mencegah batuk, menyaringkan suara, dan meningkatkan nafsu makan.[14]

b. Kunyit Asam

Jamu yang terbuat dari rebusan kunyit yang ditumbuk dengan asam jawa dan diambil airnya. Jamu kunyit asam berkhasiat untuk sebagai antibiotik dan pencegah sariawan.[14]

c. Pahitan

Jamu yang terbuat dari campuran sambiloto dengan brotowali yang direbus dan disaring untuk mendapatkan airnya. Jamu pahitan berkhasiat untuk penyembuhan penyakit gatal-gatal, sebagai jamu bersih darah, dan anti alergi.[14]

d. Gula Jahe

Ramuan yang terbuat dari campuran jahe dan gula merah yang direbus. Gula jahe memiliki khasiat untuk memperkuat pencernaan makanan, mencegah mual,menghangatkan tubuh, menurunkan tekanan darah, dan sebagainya.[15] Rebusan gula merah digunakan sebagai ramuan manisan saat mengkonsumsi jamu.

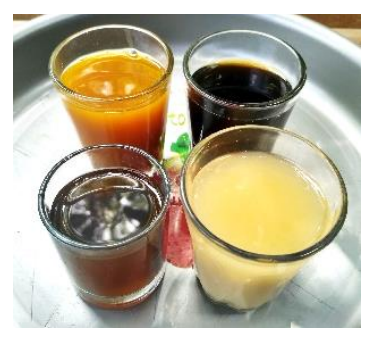

Gambar 1. Jamu
Pencampuran jamu yang biasa dilakukan oleh penjual jamu dilakukan dengan cara menuangkan jamu dari botol satu persatu. Jika pesanan jamu hanya berupa satu jenis jamu maka penjual akan menuangkan satu botol jenis jamu itu saja, jika pesanan jamu terdiri dari dua jenis jamu maka penjual akan menuangkan jamu dari dua botol sesuai dengan jenis jamu yang dipesan, dan begitupun seterusnya.

\section{Mikrokontroler Arduino 2560}

Mikrokontroler merupakan sistem komputer fungsional dalam sebuah chip. Didalamnya terdapat sebuah inti prosesor, memori, dan perangkat input output. Mikrokontroler Atmega 2560 merupakan chip mikrokontroler berbasis 8-bit AVR RISC yang memiliki performa tinggi yang memiliki flash memory $256 \mathrm{~KB}$ ISP flash memory, 8KB SRAM, 4KB EEPROM, 86 buah general purpose $\mathrm{I} / \mathrm{O}$ lines, 32 general purpose working registers, real time counter, 6 buah flexible timer/counters dengan compare modes, PWM, 4 USARTs, byte oriented 2-wire serial interface, 16channel 10-bit A/D converter, dan sebuah JTAG interface untuk on-chip debugging. Chip Atmega 2560 dapat mencapai throughput 16 MIPS pada $16 \mathrm{MHz}$ dengan tegangan operasi 4.55.5 volts. [5]

Arduino mega adalah sebuah arduino yang menggunakan ic mikrokontroler Atmega 2560. Pada board arduino mega terdapat 16 analog input, 54 digital input/output, 4 UARTs, osilator Kristal $16 \mathrm{MHz}$, soket ICSP (In-Circuit System Programming), koneksi USB, jack power, dan tombol reset. [3]

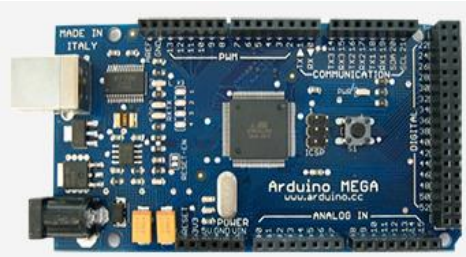

Gambar 2. Arduino Mega 2560 [6]

\section{Sensor Water Flow}

Water flow sensor merupakan sensor aliran yang berfungsi untuk mengukur laju aliran fluida. Water flow sensor terdiri dari katup 2olynom, rotor air, dan sensor half effect. Sensor ini memiliki 3 pin, yaitu pin 1 (merah) untuk VCC, pin 2 (kuning) untuk output pulsa, dan pin 3 (hitam) untuk ground.[9]

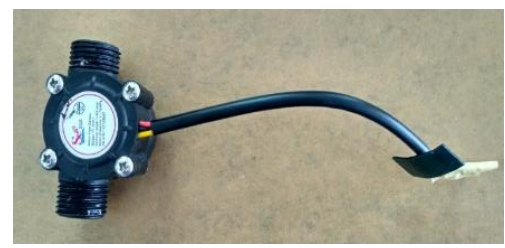

Gambar 3. Sensor Water Flow

Prinsip kerja dari water flow sensor adalah dengan adanya cairan/gas yang mengalir pada sensor akan mengakibatkan kincir pada sensor berputar. Putaran pada kincir menimbulkan medan magnet pada kumparan. Medan magnet yang dihasilkan oleh kumparan akan dikonversi oleh half effect menjadi pulsa. Putaran dari kincir bergantung kepada kekentalan cairan tersebut. Semakin kental cairan maka semakin lambatan putaran dari kincir sehingga frekuensi yang dihasilkan semakin kecil dengan bentuk high dan low, demikian sebaliknya.[9] 


\section{Sensor LDR (Light Dependent Resistor)}

Sensor LDR merupakan komponen resistor variabel yang nilai hambatannya berubah karena faktor intensitas cahaya. Prinsip kerja dari sensor LDR ketika intensitas cahaya yang mengenai permukaan sensor cukup terang, maka nilai hambatannya menjadi rendah, kira-kira 1 Kilo Ohm dan bila LDR diletakkan pada tempat yang gelap maka nilai hambatannya menjadi tinggi hingga mencapai 10 Mega Ohm. [3]

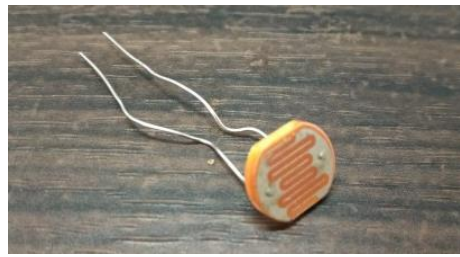

Gambar 4. Sensor LDR

\section{Solenoid Valve}

Solenoid valve merupakan katup yang digerakkan oleh aliran listrik baik AC atau DC pada kumparan yang digunakan untuk penggeraknya. Solenoid valve memiliki 2 buah saluran yaitu saluran masuk dan saluran keluar. [12]

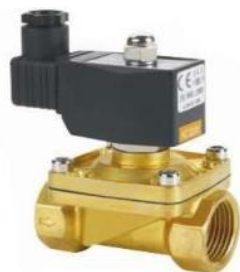

Gambar 5. Solenoid Valve [12]

Prinsip kerja dari Solenoid valve adalah ketika arus listrik yang tegangannya 100/200 V AC atau 12/24 V DC maka kumparan tersebut akan membuat pin dari katup akan tertarik yang menyebabkan cairan/gas dapat mengalir dari saluran masuk ke saluran keluar. [12]

\section{LCD (Light Crystal Display) 16x2}

LCD (liquid crystal display) 16x2 adalah display dari bahan cairan kristal yang pengoperasiannya menggunakan sistem dot matrik. LCD 16x2 dapat menampilkan sebanyak 32 karakter yang terdiri dari 2 baris dan tiap baris dapat menampilkan 16 karakter. [3]

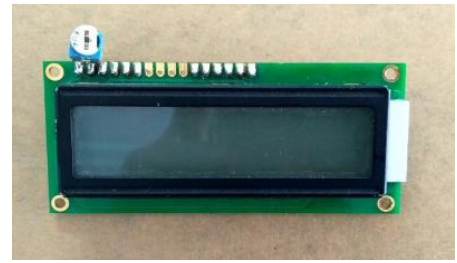

Gambar 6. LCD (Light Crystal Display)

\section{Keypad}

Keypad adalah Matrik yang dibentuk beberapa buah saklar dengan tujuan penghematan jalur input/output. Cara menggunakan keypad dengan metode scanning, dimana setiap baris diberi logik 0 secara bergilir dan set seluruh kolom berlogik 1. Apabila ada kolom yang terbaca logik 0 , berati kolom tersebut sedang ditekan. [3]

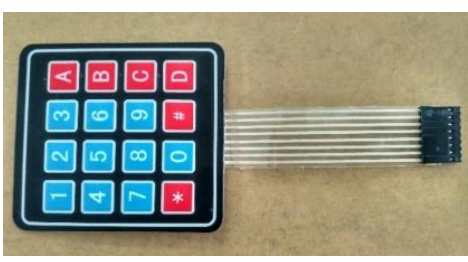

Gambar 7. Keypad

\section{Relay}

Relay merupakan komponen yang menggunakan gaya elektromagnetik untuk menutup/membuka kontak saklar yang digerakkan oleh daya/energi listrik. Fungsi dari relay sebagai berikut [10] :

a. Remote Control : digunakan untuk menyalakan atau mematikan alat dari jarak jauh.

b. Penguat Daya : digunakan untuk menguatkan tegangan atau arus.

Prinsip kerja dari relay adalah ketika kawat mendapat energy listrik, mengakibatkan adanya gaya elektromagnet yang akan menarik bagian yang berpegas, dan kontak akan menutup.[10]

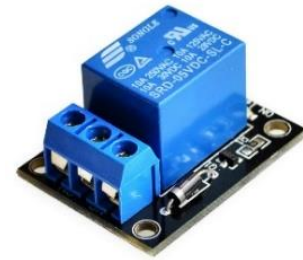

Gambar 8. Relay [11]

\section{Motor DC (Dirrect Current)}

Motor DC merupakan perangkat elektromagnetik yang dapat mengubah energi listrik menjadi energi mekanik, dimana tenaga mekanik yang dihasilkan berupa putaran pada rotor. Motor DC bekerja dengan memerlukan suplay tegangan DC (searah) sebesar 1,5 volt sampai dengan 24 volt. [16]

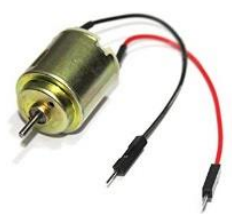

Gambar 9. Motor DC [17]

\section{METODOLOGI PENELITIAN}

Penelitian yang digunakan dalam penulisan tugas akhir ini adalah penelitian eksperimen. Penelitian eksperimen merupakan jenis penelitian yang digunakan untuk melihat hubungan sebab akibat yang dapat mencari pengaruh perlakuan terhadap subjek atau variabel tertentu.

\section{Rancangan Umum Sistem}

Perancangan umum sistem dilakukan untuk menggambarkan rancangan perangkat keras secara keseluruhan. Perangkat keras yang digunakan pada sistem ini terdiri dari gelas, arduino mega, solenoid valve, water flow sensor, sensor LDR, relay, keypad, $\mathrm{LCD}$, dan motor DC. 
Adapun fungsi dari masing-masing perangkat keras antara lain :

a. Arduino Mega

Arduino mega berfungsi sebagai mikrokontroler yang digunakan sebagai pengontrol utama dari sistem.

b. Sensor LDR

Sensor LDR berfungsi untuk mendeteksi keberadaan gelas.

c. Relay

Relay berfungsi sebagai saklar otomatis yang digunakan untuk mengaktifkan solenoid valve.

d. Solenoid Valve

Solenoid valve berfungsi sebagai katup yang dapat menahan dan mengalirkan jamu yang akan mengalir ke gelas.

e. Water Flow Sensor

Water flow sensor berfungsi untuk menghitung banyaknya volume jamu yang mengalir ke gelas.

f. Keypad

Keypad berfungsi untuk memasukkan kode menu dari jenis jamu yang akan dipilih.

g. LCD (Liquid Crystal Display)

LCD berfungsi untuk menampilkan kode menu dan menu yang dipilih.

h. Motor DC

Motor DC berfungsi untuk menggerakkan atau memutarkan pengaduk.

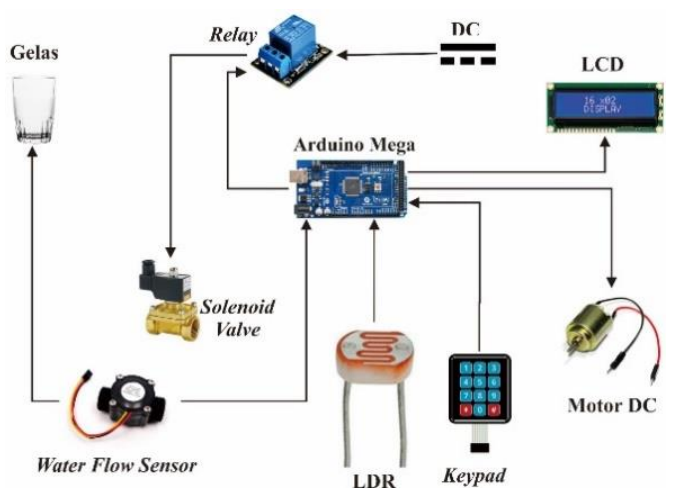

Gambar 10. Skema Rancangan Sistem

Berdasarkan Gambar 10 diatas mengenai skema rancangan sistem, dimana sistem pencampuran jamu merupakan perangkatperangkat keras yang saling berhubungan sehingga fungsi dari masing-masing perangkat keras dapat berjalan pada pencampuran jamu.

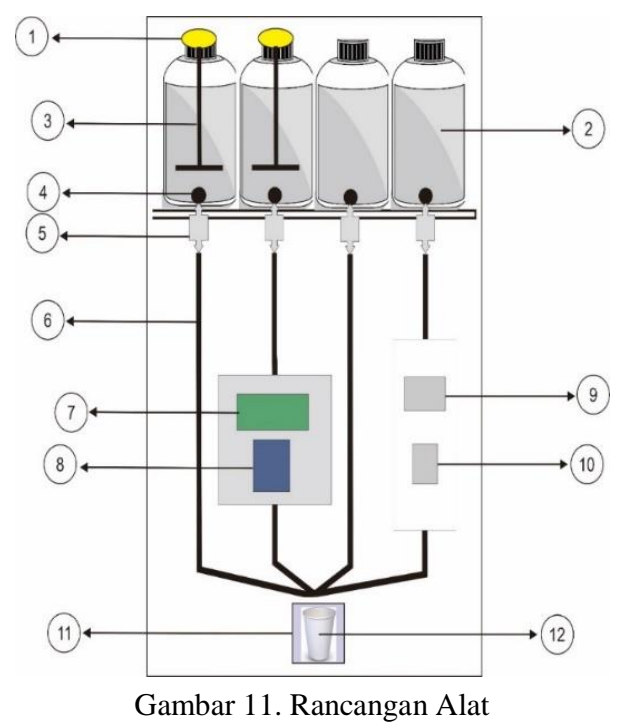

https://doi.org/10.25077/jitce.3.01.8-17.2019
Berdasarkan gambar diatas, berikut ini uraian dari beberapa perangkat yang digunakan pada rancangan alat adalah sebagai berikut :
1. Motor DC
2. Botol Jamu
7. LCD (Liquid Crystal Display)
3. Pengaduk
4. Solenoid Valve
5. Water Flow Sensor
8. Keypad
9. Arduino Mega
10. Relay
11. Sensor LDR
6. Pipa / Selang
12. Gelas

\section{Rancangan Proses}

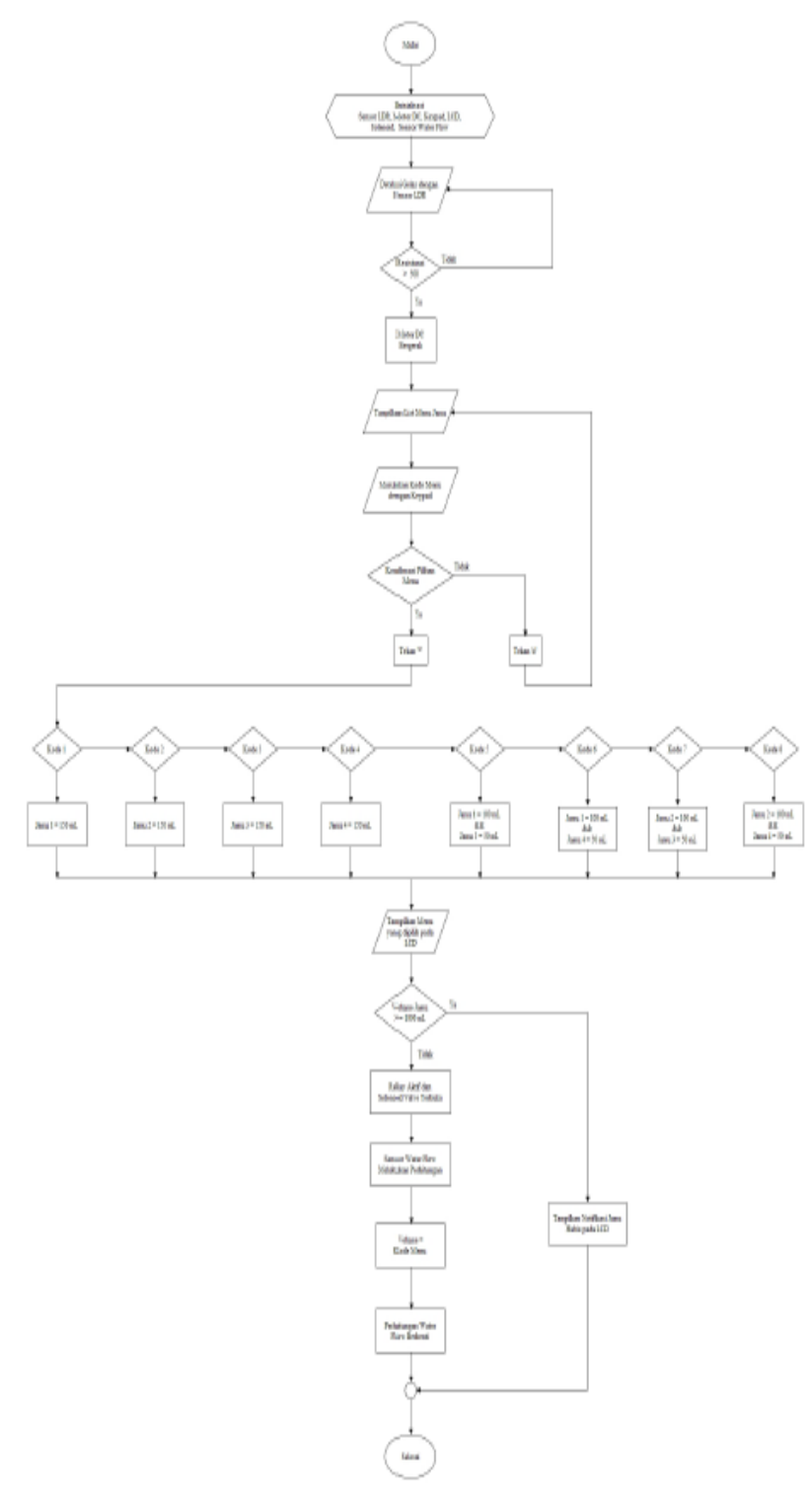

Gambar 12. Flowchart Rancangan Sistem Umum

Berdasarkan flowchart pada Gambar 12 tersebut, sistem pencampuran dari beberapa jenis jamu dapat dilakukan terlebih dahulu dengan cara membuat gelas terdeteksi oleh sensor LDR. Gelas akan dideteksi oleh sensor LDR dengan resistansi besar dari 500. Jika sensor mendeteksi adanya keberadaan dari gelas dengan jarak tersebut, maka sistem akan aktif dengan menggunakan relay sebagai saklarnya. Setelah sistem aktif, maka motor DC akan aktif yang mengakibatkan pengaduk dapat berputar dan LCD akan menampilkan menu apa yang akan dipilih sesuai dengan kode yang telah ditetapkan, kode akan dimasukkan dengan menggunakan keypad. 
Pemilihan kode tersebut diinisialisasikan bahwa beras kencur sebagai jamu 1, kunyit asam sebagai jamu 2, pahitan sebagai jamu 3, dan gula jahe sebagai jamu 4. Setelah pemilihan menu telah dilakukan dengan keypad, maka LCD akan menampilkan menu yang dipilih tersebut dan katup (solenoid valve) akan terbuka sehingga jamu akan mengalir ke gelas dengan melalui sensor water flow. Sensor water flow akan menghitung volume jamu yang mengalir. Saat volume jamu di masing-masing botol telah mencapai volume maksimal sebesar $>=1000 \mathrm{~mL}$, maka arduino akan mengirimkan notifikasi ke LCD bahwa jamu habis.

\section{HASIL DAN PEMBAHASAN}

\section{Implemetasi Perangkat Keras}

Rancang bangun alat pencampur minuman jamu otomatis dibangun dengan menggunakan perangkat keras berupa arduino mega, sensor LDR, motor DC, keypad, LCD, solenoid valve, relay, water flow sensor.

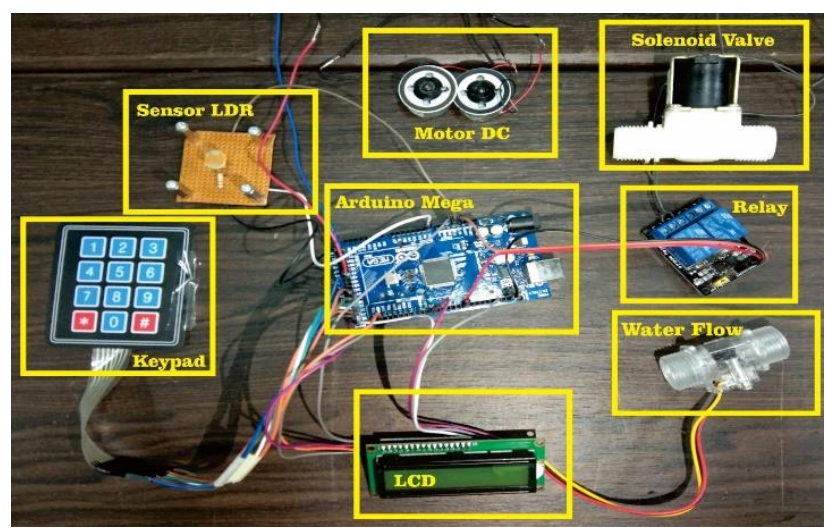

Gambar 13. Implementasi Perangkat Keras

Fungsi dari masing-masing perangkat keras antara lain :

a. Arduino Mega

Arduino mega berfungsi sebagai mikrokontroler yang digunakan sebagai pengontrol utama dari sistem.

b. Sensor LDR (Light Dependent Resistor)

Sensor LDR berfungsi untuk mendeteksi keberadaan gelas.

c. Motor DC

Motor DC berfungsi untuk menggerakkan atau memutarkan pengaduk.

d. Keypad

Keypad berfungsi untuk memasukkan kode menu dari jenis jamu yang akan dipilih.

e. LCD (Liquid Crystal Display)

LCD berfungsi untuk menampilkan kode menu dan menu yang dipilih.

f. Relay

Relay berfungsi sebagai saklar otomatis yang digunakan untuk mengaktifkan solenoid valve.

g. Solenoid Valve

Solenoid valve berfungsi sebagai katup yang dapat menahan dan mengalirkan jamu yang akan mengalir ke gelas.

h. Water Flow Sensor

Water flow sensor berfungsi untuk menghitung banyaknya volume jamu yang mengalir ke gelas.
Komponen - komponen pada implementasi perangkat keras untuk rancang bangun sistem pencampur minuman jamu otomatis akan dihubungkan ke pin-pin arduino mega yang digunakan sebagai pengontrol utama dari sistem, skema dari hubungan pinpin komponen ditunjukkan seperti gambar 14 berikut ini.

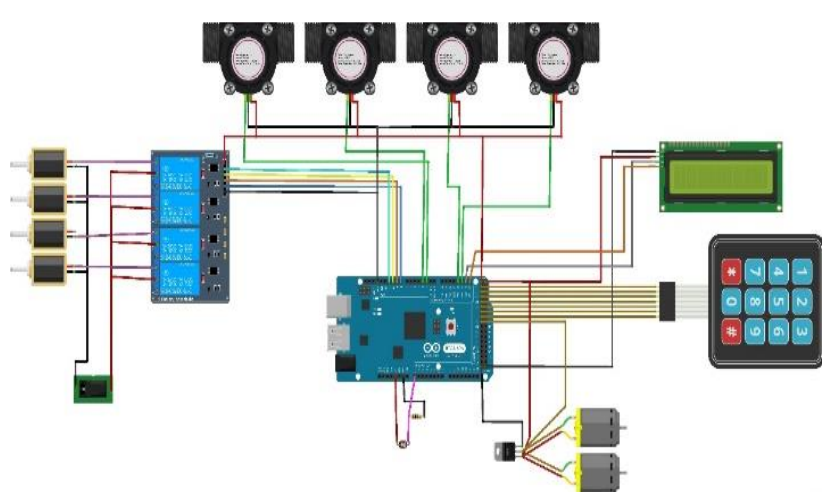

Gambar 14. Skema Implementasi Perangkat Keras

\section{Implemetasi Sistem}

Implementasi sistem pencampur minuman otomatis dapat ditunjukkan pada gambar berikut ini.

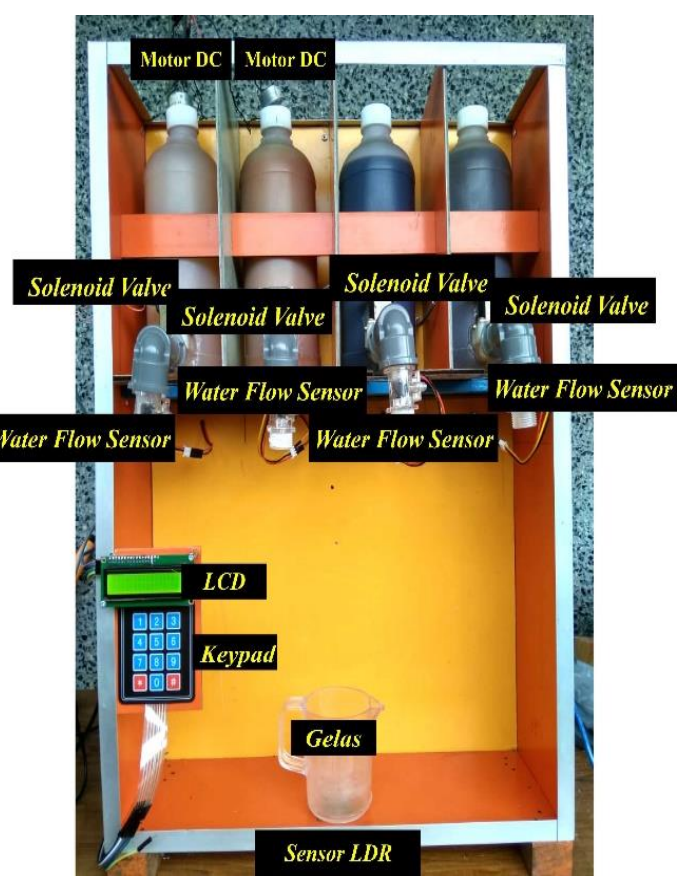

Gambar 14.a Implementasi Sistem Tampak Depan

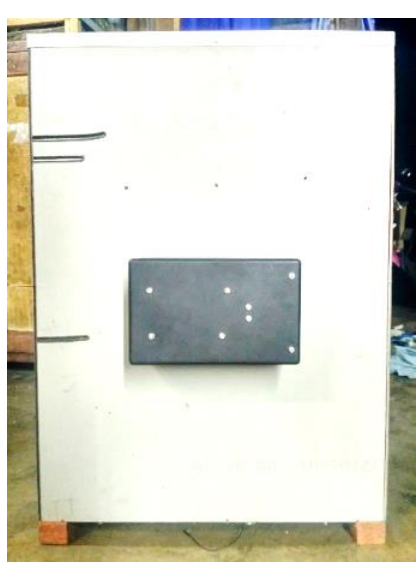

Gambar 14.b Implementasi Sistem Tampak Belakang 


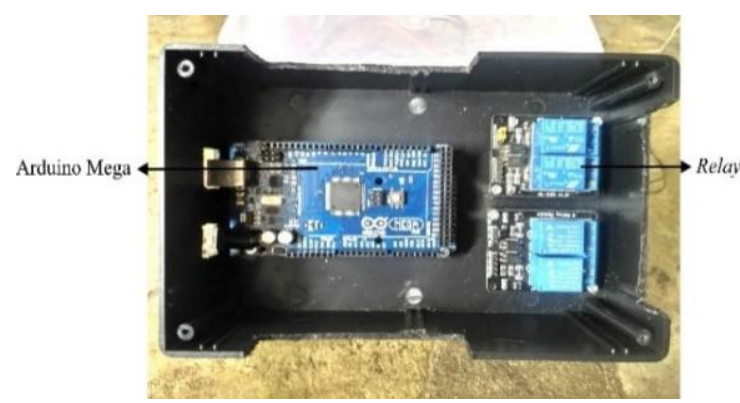

Gambar 14.c Implementasi Sistem Tampak Dalam Kotak

Berdasarkan Gambar 14.a diatas, rancang bangun alat pencampur minuman jamu otomatis dibuat berupa kotak, dengan ukuran sebagai berikut :

Panjang : $45 \mathrm{~cm}$

Lebar $\quad: 15 \mathrm{~cm}$

Tinggi $: 60 \mathrm{~cm}$

Penelitian ini menggunakan 4 buah botol jamu yang terdiri dari botol 1 untuk jamu beras kencur, botol 2 untuk jamu kunyit asam, botol 3 untuk jamu pahitan, dan botol 4 untuk jamu gula jahe. Pada botol 1 dan botol 2 terdapat alat untuk mengaduk jamu dengan menggunakan motor DC dikarenakan jenis jamu beras kencur dan kunyit asam memiliki serbuk. Rancang bangun ini juga menggunakan solenoid valve yang digunakan sebagai katup saat akan mengalirkan jamu ke gelas dan jamu yang mengalir akan dibaca oleh sensor water flow. Jamu yang mengalir dari botol jamu akan ditampung ke gelas yang sebelumnya sudah dideteksi keberadaannya oleh sensor LDR. Dalam menentukan pilihan menu jamu yang akan dicampur ke gelas, sistem menggunakan keypad untuk kode jamu dari pilihan menu yang disediakan dan pilihan menu akan ditampilkan pada LCD.

\section{Pengujian Sensor LDR (Light Dependent Resistor)}

Pengujian sensor LDR dilakukan untuk membaca respon dari sensor jika sensor mendeteksi adanya gelas. Sensor LDR dalam pengujian akan menghasilkan keadaan "Terhalang" dan "Tidak Terhalang". Sensor dikatakan "Terhalang" ketika nilai hambatan yang diterima oleh sensor "besar dari 500 ohm". Nilai hambatan disebut juga dengan nilai resistansi. Nilai resistansi pada sensor akan kecil pada saat cahaya terang dan nilai resistansi akan menjadi besar jika dalam kondisi gelap atau tidak mendapatkan cahaya.

Berdasarkan pengujian yang telah dilakukan, maka pengujian dapat direpresentasikan pada tabel berikut ini.

Tabel 1. Pengujian Sensor LDR

\begin{tabular}{|c|c|c|c|}
\hline $\begin{array}{c}\text { Percobaan } \\
\text { ke- }\end{array}$ & Nilai Resistansi & Gelas Terdeteksi & Keterangan \\
\hline 1 & 276 & Tidak Terdeteksi & Tidak Terhalang \\
\hline 2 & 288 & Tidak Terdeteksi & Tidak Terhalang \\
\hline 3 & 265 & Tidak Terdeteksi & Tidak Terhalang \\
\hline 4 & 309 & Tidak Terdeteksi & Tidak Terhalang \\
\hline 5 & 353 & Tidak Terdeteksi & Tidak Terhalang \\
\hline 6 & 532 & Terdeteksi & Terhalang \\
\hline 7 & 519 & Terdeteksi & Terhalang \\
\hline 8 & 590 & Terdeteksi & Terhalang \\
\hline 9 & 604 & Terdeteksi & Terhalang \\
\hline 10 & 678 & Terdeteksi & Terhalang \\
\hline
\end{tabular}

Nilai resistansi merupakan nilai hambatan yang dihasilkan oleh sensor LDR saat melakukan pengujian, jika nilai resistansinya terbaca oleh sensor dari rentang 0-500 ohm maka dapat dikatakan bahwa kondisi sensor mendapatkan cahaya, sedangkan jika nilai resistansi terbaca oleh sensor lebih dari $500 \mathrm{ohm}$ maka dapat dikatakan bahwa kondisi sensor tidak mendapatkan cahaya atau dalam keadaan terhalang.

\section{Pengujian Motor DC}

Pengujian pada motor DC dilakukan untuk menentukan berputarnya 2 (dua) buah motor DC yang bergantung pada kondisi sensor LDR. Pengujian pada motor DC berfungsi untuk menggerakkan atau membuat pengaduk yang ada pada alat berputar. Motor DC akan aktif atau menghasilkan rotor berputar saat kondisi sensor LDR "Terhalang" dikarenakan terdeteksi adanya gelas.

Berdasarkan pengujian yang telah dilakukan, maka pengujian motor DC yang dilakukan dapat direpresentasikan pada Tabel berikut ini.

Tabel 2. Pengujian Motor DC

\begin{tabular}{|c|c|c|}
\hline Percobaan Ke- & Kondisi LDR & Hasil Motor DC \\
\hline 1 & Tidak Terhalang & Tidak Aktif \\
\hline 2 & Tidak Terhalang & Tidak Aktif \\
\hline 3 & Tidak Terhalang & Tidak Aktif \\
\hline 4 & Tidak Terhalang & Tidak Aktif \\
\hline 5 & Tidak Terhalang & Tidak Aktif \\
\hline 6 & Terhalang & Aktif \\
\hline 7 & Terhalang & Aktif \\
\hline 8 & Terhalang & Aktif \\
\hline 9 & Terhalang & Aktif \\
\hline 10 & Terhalang & Aktif \\
\hline
\end{tabular}

Berdasarkan tabel 2 tersebut, motor DC akan aktif saat kondisi sensor LDR "Terhalang" dan motor DC tidak aktif saat kondisi sensor LDR “Tidak Terhalang”.

\section{Pengujian Keypad}

Pengujian keypad dilakukan untuk membaca inputan dari keypad berupa "Kode Menu" mengenai pilihan menu campuran 4 (empat) jenis jamu yaitu jamu beras kencur, kunyit asam, pahitan, dan gula jahe. Kode menu akan dibaca sesuai inputan dari tombol keypad dimensi 3x4 yaitu berupa "Kode Menu" yakni tombol 1, tombol 2, tombol 3, tombol 4, tombol 5, tombol 6, tombol 7, tombol 8, tombol 9, tombol *, tombol 0, dan tombol \#. Pembacaan dari inputan keypad akan ditampilkan pada LCD.
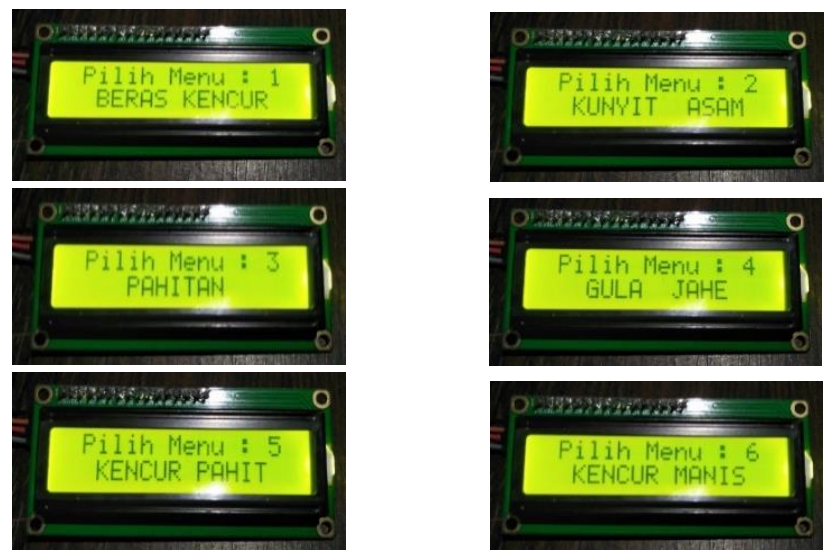

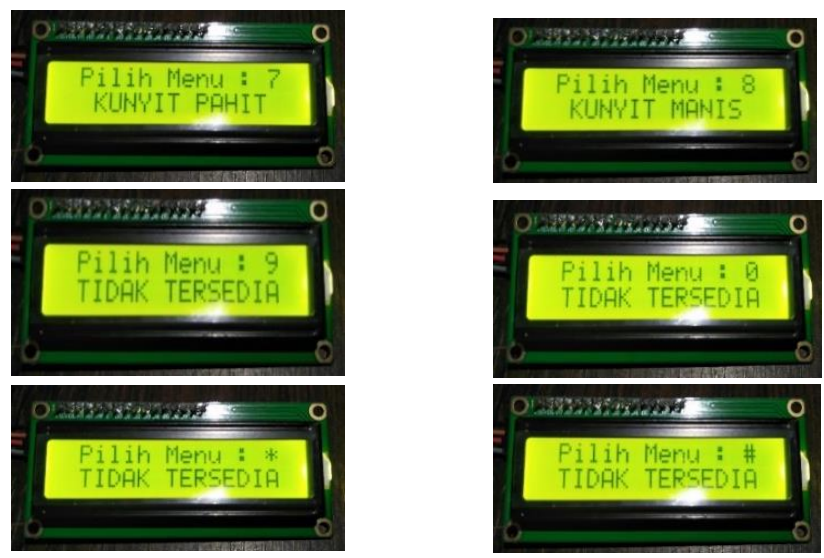

Gambar 15. Tampilan Pilihan Menu pada LCD oleh Keypad

Berdasarkan gambar 15, saat tombol 1 ditekan, maka "Kode 1" yang tampil dan menampilkan menu "Jamu Beras Kencur", saat tombol 2 ditekan, maka "Kode 2 yang tampil dan menampilkan menu "Jamu Kunyit Asam", saat tombol 3 ditekan, maka "Kode 3" yang tampil dan menampilkan menu "Jamu Pahitan", saat tombol 4 ditekan, maka "Kode 4" yang tampil dan menampilkan menu "Jamu Gula Jahe", saat tombol 5 ditekan, maka "Kode 5" yang tampil dan menampilkan menu campuran dari "Jamu Beras Kencur dan Pahitan", saat tombol 6 ditekan, maka "Kode 6" yang tampil dan menampilkan menu campuran dari "Jamu Beras Kencur dan Gula Jahe", saat tombol 7 ditekan, maka "Kode 7" yang tampil dan menampilkan menu campuran dari "Jamu Kunyit Asam dan Pahitan", saat tombol 8 ditekan, maka "Kode 9" yang tampil dan menampilkan menu campuran dari "Jamu Beras Kencur dan Pahitan", sedangkan jika (tombol 9, *, 0, \#) yang ditekan maka yang tampil adalah "Menu Tidak Tersedia".

\section{Pengujian Solenoid Valve}

Pengujian solenoid valve dilakukan untuk melihat apakah katup pada solenoid valve 12 volt akan terbuka atau tidak. Pengujian dilakukan dengan memberikan variasi tegangan input mulai dari tegangan 3,3 volt sampai 12 volt. Pengujian solenoid valve dapat dilihat pada tabel 3 berikut ini.

Tabel 3. Pengujian Solenoid Valve

\begin{tabular}{|c|c|c|}
\hline Percobaan Ke- & Tegangan Masuk & Kondisi Solenoid Valve \\
\hline 1 & 3 volt & Katup Tidak Terbuka \\
\hline 2 & 4,5 volt & Katup Terbuka Sedikit \\
\hline 3 & 6 volt & Katup Terbuka \\
\hline 4 & 7,5 volt & Katup Terbuka \\
\hline 5 & 9 volt & Katup Terbuka \\
\hline 6 & 12 volt & Katup Terbuka Penuh \\
\hline
\end{tabular}

Pada tabel 3, solenoid valve 12 volt dapat bekerja dengan tegangan masuk pada rangkaian dari 4,5 volt hingga 12 volt. Namun saat tegangan yang diberikan 4,5 volt katup hanya terbuka sedikit, sedangkan saat tegangan yang diberikan 12 volt katup terbuka penuh.

\section{Pengujian Sensor Water Flow}

Pengujian sensor water flow dilakukan untuk mengetahui berapa debit air yang mengalir dengan menggunakan sensor water flow. Pengujian sensor water flow diperoleh berupa pulse dengan nilai bervariasi yang membutuhkan faktor pengali untuk mengkonversi freakuensi ke satuan jumlah volume berdasarkan persamaan berikut :
Pulsa Frequency $=$ Faktor Kalibrasi * Q

Pengujian sensor water flow ini dilakukan untuk mengubah faktor kalibrasi sensor untuk mengetahui faktor kalibrasi yang cocok dalam pengukuran volume berdasarkan persamaan berikut :

Kecepatan aliran $/$ menit = pulsa Frequency $/$ Faktor Kalibrasi

Kecepatan aliran per detik = Kecepatan aliran $/ 60 * 1000$

Dimana :

a. Pulsa Frequency merupakan sinyal keluaran dari Sensor Hall Effect yang terdapat pada sensor water flow.

b. Faktor Kalibrasi merupakan sebuah nilai yang diatur untuk mengatur akurasi pembacaan sensor.

c. Q merupakan debit air dalam satuan Liter/menit (L/min).

Pengujian Faktor Kalibrasi 3.7 untuk Volume $150 \mathrm{~mL}$

Tabel 4. Pengujian Faktor Kalibrasi 3.7

\begin{tabular}{|c|c|c|c|}
\hline $\begin{array}{c}\text { Percobaan } \\
\text { Ke- }\end{array}$ & Volume Mutlak (ml) & $\begin{array}{c}\text { Volume Pada Gelas } \\
\text { Ukur (ml) }\end{array}$ & Selisih (ml) \\
\hline 1 & 150 & 153 & 3 \\
\hline 2 & 150 & 153 & 3 \\
\hline 3 & 150 & 152 & 2 \\
\hline 4 & 150 & 150 & 2 \\
\hline 5 & 150 & 152 & 10 \\
\hline \multicolumn{3}{|c|}{ Jumlah Selisih } \\
\hline
\end{tabular}

Berdasarkan tabel 4, rata-rata selisih volume antar volume pembacaan sensor yang diukur menggunakan gelas ukur dengan volume mutlak yaitu $150 \mathrm{~mL}$ dan diperoleh sebesar $2 \mathrm{~mL}$.

Pengujian Faktor Kalibrasi 2.9 untuk Volume $100 \mathrm{~mL}$ Tabel 5. Pengujian Faktor Kalibrasi 2.9

\begin{tabular}{|c|c|c|c|}
\hline $\begin{array}{c}\text { Percobaan } \\
\text { Ke- }\end{array}$ & Volume Mutlak (ml) & $\begin{array}{c}\text { Volume Pada Gelas } \\
\text { Ukur (ml) }\end{array}$ & Selisih (ml) \\
\hline 1 & 100 & 100 & 0 \\
\hline 2 & 100 & 99 & 1 \\
\hline 3 & 100 & 99 & 1 \\
\hline 4 & 100 & 98 & 2 \\
\hline 5 & 100 & 99 & 1 \\
\hline \multicolumn{3}{|c|}{ Jumlah Selisih } \\
\hline \multicolumn{3}{|c|}{ Rata-rata Selisih } \\
\hline
\end{tabular}

Berdasarkan tabel 5, rata-rata selisih volume antar volume pembacaan sensor yang diukur menggunakan gelas ukur dengan volume mutlak yaitu $150 \mathrm{~mL}$ dan diperoleh sebesar $1 \mathrm{~mL}$.

Pengujian Faktor Kalibrasi 1.2 untuk Volume $50 \mathrm{~mL}$

Tabel 6. Pengujian Faktor Kalibrasi 1.2

\begin{tabular}{|c|c|c|c|}
\hline $\begin{array}{c}\text { Percobaan } \\
\text { Ke- }\end{array}$ & Volume Mutlak (ml) & $\begin{array}{c}\text { Volume Pada Gelas } \\
\text { Ukur (ml) }\end{array}$ & Selisih (ml) \\
\hline 1 & 50 & 49 & 1 \\
\hline 2 & 50 & 49 & 1 \\
\hline 3 & 50 & 48 & 2 \\
\hline 4 & 50 & 50 & 0 \\
\hline 5 & 50 & 50 & 0 \\
\hline \multicolumn{3}{|c|}{ Jumlah Selisih } \\
\hline \multicolumn{3}{|c|}{ Rata-rata Selisih } \\
\hline
\end{tabular}

Berdasarkan tabel 6, rata-rata selisih volume antar volume pembacaan sensor yang diukur menggunakan gelas ukur dengan volume mutlak yaitu $150 \mathrm{~mL}$ dan diperoleh sebesar $0.8 \mathrm{~mL}$. 


\section{Pengujian Sistem}

Pemilihan Kode '1' untuk Jamu Beras Kencur

Pengujian pemilihan menu dengan kode ' 1 ' dapat ditunjukkan pada tabel berikut.

Tabel 7. Pengujian Pemilihan Kode ' 1 '

\begin{tabular}{|c|c|c||}
\hline \multirow{2}{*}{$\begin{array}{c}\text { Percobaan } \\
\text { ke - }\end{array}$} & \multicolumn{2}{|c|}{ Jamu Beras Kencur } \\
\cline { 2 - 3 } & Volume Mutlak (ml) & Volume Pada Gelas Ukur (ml) \\
\hline 1 & 150 & 152 \\
\hline 2 & 150 & 150 \\
\hline 3 & 150 & 151 \\
\hline 4 & 150 & 150 \\
\hline 5 & 150 & 151 \\
\hline
\end{tabular}

Pengujian pemilihan kode ' 1 ' dilakukan dengan cara menekan tombol inputan ' 1 ' pada keypad. Setelah tombol ditekan, solenoid valve akan membuka katup sehingga jamu beras kencur pada botol 1 mengalir dan jamu yang mengalir akan dihitung volumenya oleh sensor water flow. Dan pengujian pemilihan kode ' 1 ' dapat mengeluarkan jamu beras kencur dengan volume antara $150-152 \mathrm{~mL}$.

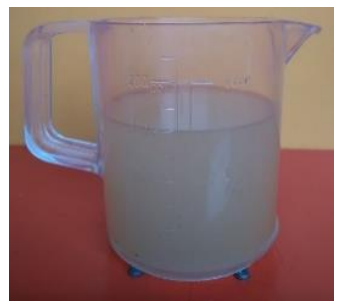

Gambar 16. Jamu Hasil Pengujian Pemilihan Kode '1'

Pemilihan Kode '2' untuk Jamu Kunyit Asam

Pengujian pemilihan menu dengan kode '2' dapat ditunjukkan pada tabel berikut.

Tabel 8. Pengujian Pemilihan Kode '2'

\begin{tabular}{|c|c|c|}
\hline \multirow{2}{*}{$\begin{array}{c}\text { Percobaan } \\
\text { ke - }\end{array}$} & \multicolumn{2}{|c|}{ Jamu Kunyit Asam } \\
\cline { 2 - 3 } & Volume Mutlak (ml) & Volume Pada Gelas Ukur (m) \\
\hline 1 & 150 & 152 \\
\hline 2 & 150 & 151 \\
\hline 3 & 150 & 151 \\
\hline 4 & 150 & 150 \\
\hline 5 & 150 & 151 \\
\hline
\end{tabular}

Pengujian pemilihan kode ' 2 ' dilakukan dengan cara menekan tombol inputan '2' pada keypad. Setelah tombol ditekan, solenoid valve akan membuka katup sehingga jamu kunyit asam pada botol 2 mengalir dan jamu yang mengalir akan dihitung volumenya oleh sensor water flow. Dan pengujian pemilihan kode '2' dapat mengeluarkan jamu kunyit asam dengan volume antara $150-152$ $\mathrm{mL}$.

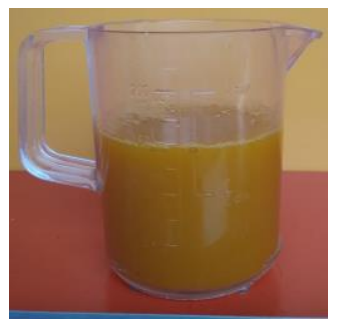

Gambar 17. Jamu Hasil Pengujian Pemilihan Kode '2'
Pemilihan Kode '3' untuk Jamu Pahitan

Pengujian pemilihan menu dengan kode ' 3 ' dapat ditunjukkan pada tabel berikut.

Tabel 9. Pengujian Pemilihan Kode ' 3 '

\begin{tabular}{|c|c|c|}
\hline \multirow{2}{*}{$\begin{array}{c}\text { Percobaan } \\
\text { ke }-\end{array}$} & \multicolumn{2}{|c|}{ Jamu Pahitan } \\
\cline { 2 - 3 } & Volume Mutlak (ml) & Volume Pada Gelas Ukur (m) \\
\hline 1 & 150 & 151 \\
\hline 2 & 150 & 150 \\
\hline 3 & 150 & 150 \\
\hline 4 & 150 & 151 \\
\hline 5 & 150 & 151 \\
\hline
\end{tabular}

Pengujian pemilihan kode ' 3 ' dilakukan dengan cara menekan tombol inputan '3' pada keypad. Setelah tombol ditekan, solenoid valve akan membuka katup sehingga jamu pahitan pada botol 3 mengalir dan jamu yang mengalir akan dihitung volumenya oleh sensor water flow. Dan pengujian pemilihan kode ' 3 ' dapat mengeluarkan jamu pahitan dengan volume antara 150 - $151 \mathrm{~mL}$.

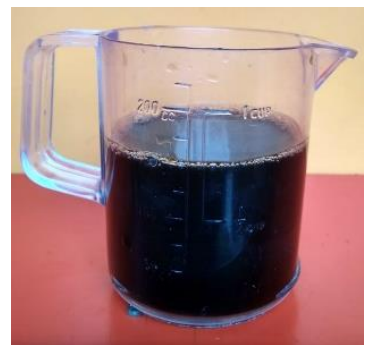

Gambar 18. Jamu Hasil Pengujian Pemilihan Kode '3'

Pemilihan Kode '4' untuk Jamu Gula Jahe

Pengujian pemilihan menu dengan kode '4' dapat ditunjukkan pada tabel berikut.

Tabel 10. Pengujian Pemilihan Kode '4'

\begin{tabular}{|c|c|c|}
\hline \multirow{2}{*}{$\begin{array}{c}\text { Percobaan } \\
\text { ke - }\end{array}$} & \multicolumn{2}{|c|}{ Jamu Gula Jahe } \\
\cline { 2 - 3 } & Volume Mutlak (ml) & $\begin{array}{c}\text { Volume Pada Gelas Ukur } \\
\text { (ml) }\end{array}$ \\
\hline 1 & 150 & 151 \\
\hline 2 & 150 & 151 \\
\hline 3 & 150 & 150 \\
\hline 4 & 150 & 152 \\
\hline 5 & 150 & 150 \\
\hline
\end{tabular}

Pengujian pemilihan kode '4' dilakukan dengan cara menekan tombol inputan '4' pada keypad. Setelah tombol ditekan, solenoid valve akan membuka katup sehingga jamu gula jahe pada botol 4 mengalir dan jamu yang mengalir akan dihitung volumenya oleh sensor water flow. Dan pengujian pemilihan kode ' 4 ' dapat mengeluarkan jamu gula jahe dengan volume antara 150 - 152 $\mathrm{mL}$.

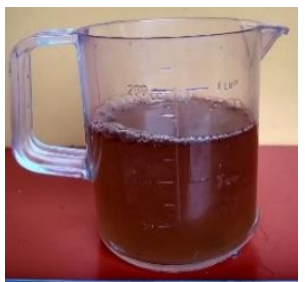

Gambar 19. Jamu Hasil Pengujian Pemilihan Kode '4' 
Pemilihan Kode '5' untuk Jamu Beras Kencur dan Pahitan

Pengujian pemilihan menu dengan kode ' 5 ' dapat ditunjukkan pada tabel berikut.

Tabel 11. Pengujian Pemilihan Kode '5'

\begin{tabular}{|c|c|c|c|c|}
\hline \multirow{2}{*}{$\begin{array}{c}\text { Percobaan } \\
\text { ke- }\end{array}$} & \multicolumn{2}{|c|}{ Jamu Beras Kencur } & \multicolumn{2}{c|}{ Jamu Pahitan } \\
\cline { 2 - 5 } & $\begin{array}{c}\text { Volume } \\
\text { Mutlak (ml) }\end{array}$ & $\begin{array}{c}\text { Volume pada } \\
\text { Gelas Ukur } \\
(\mathbf{m l})\end{array}$ & $\begin{array}{c}\text { Volume } \\
\text { Mutlak (m) }\end{array}$ & $\begin{array}{c}\text { Volume pada } \\
\text { Gelas Ukur } \\
\text { (m) }\end{array}$ \\
\hline 1 & 100 & 99 & 50 & 49 \\
\hline 2 & 100 & 99 & 50 & 49 \\
\hline 3 & 100 & 100 & 50 & 50 \\
\hline 4 & 100 & 98 & 50 & 49 \\
\hline 5 & 100 & 99 & 50 & 48 \\
\hline
\end{tabular}

Pengujian pemilihan kode ' 5 ' dilakukan dengan cara menekan tombol inputan ' 5 ' pada keypad. Setelah tombol ditekan, solenoid valve akan membuka katup sehingga jamu beras kencur pada botol 1 dan jamu pahitan pada botol 3 mengalir, selanjutnya jamu yang mengalir akan dihitung volumenya oleh sensor water flow. Dan pengujian pemilihan kode ' 5 ' dapat mengeluarkan jamu beras kencur dan pahitan dengan jumlah volume antara 148 - 150 $\mathrm{mL}$.

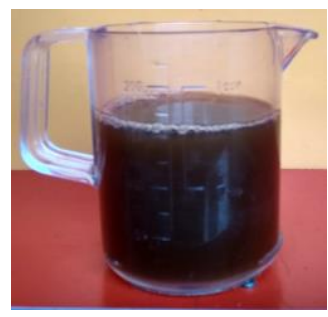

Gambar 20. Jamu Hasil Pengujian Pemilihan Kode '5'

Pemilihan Kode '6' untuk Jamu Beras Kencur dan Gula Jahe Pengujian pemilihan menu dengan kode ' 6 ' dapat ditunjukkan pada tabel berikut.

Tabel 12. Pengujian Pemilihan Kode '6'

\begin{tabular}{|c|c|c|c|c||}
\hline \multirow{2}{*}{$\begin{array}{c}\text { Percobaan } \\
\text { ke- }\end{array}$} & \multicolumn{2}{|c|}{ Jamu Beras Kencur } & \multicolumn{2}{c|}{ Jamu Gula Jahe } \\
\cline { 2 - 5 } & $\begin{array}{c}\text { Volume } \\
\text { Mutlak (ml) }\end{array}$ & $\begin{array}{c}\text { Volume pada } \\
\text { Gelas Ukur } \\
(\mathbf{m l})\end{array}$ & $\begin{array}{c}\text { Volume } \\
\text { Mutlak (ml) }\end{array}$ & $\begin{array}{c}\text { Volume pada } \\
\text { Gelas Ukur } \\
(\mathbf{m l})\end{array}$ \\
\hline 1 & 100 & 99 & 50 & 50 \\
\hline 2 & 100 & 100 & 50 & 49 \\
\hline 3 & 100 & 98 & 50 & 49 \\
\hline 4 & 100 & 100 & 50 & 49 \\
\hline 5 & 100 & 98 & 50 & 48 \\
\hline
\end{tabular}

Pengujian pemilihan kode ' 6 ' dilakukan dengan cara menekan tombol inputan '6' pada keypad. Setelah tombol ditekan, solenoid valve akan membuka katup sehingga jamu beras kencur pada botol 1 dan jamu gula jahe pada botol 4 mengalir, selanjutnya jamu yang mengalir akan dihitung volumenya oleh sensor water flow. Dan pengujian pemilihan kode ' 6 ' dapat mengeluarkan jamu beras kencur dan gula jahe dengan jumlah volume antara $147-149 \mathrm{~mL}$.

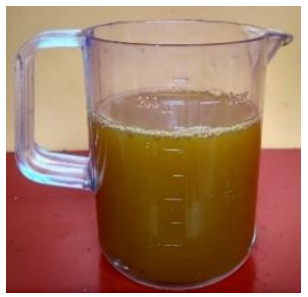

Gambar 21. Jamu Hasil Pengujian Pemilihan Kode '6'
Kode '7' untuk Jamu Kunyit Asam dan pahitan

Pengujian pemilihan menu dengan kode ' 7 ' dapat ditunjukkan pada tabel berikut.

Tabel 13. Pengujian Pemilihan Kode '7'

\begin{tabular}{|c|c|c|c|c|}
\hline \multirow{2}{*}{$\begin{array}{c}\text { Percobaan } \\
\text { ke- }\end{array}$} & \multicolumn{2}{|c|}{ Jamu Beras Kencur } & \multicolumn{2}{c|}{ Jamu Pahitan } \\
\cline { 2 - 5 } & $\begin{array}{c}\text { Volume } \\
\text { Mutlak (ml) }\end{array}$ & $\begin{array}{c}\text { Volume pada } \\
\text { Gelas Ukur } \\
(\mathbf{m l})\end{array}$ & $\begin{array}{c}\text { Volume } \\
\text { Mutlak } \\
(\mathbf{m l})\end{array}$ & $\begin{array}{c}\text { Volume pada } \\
\text { Gelas Ukur } \\
(\mathbf{m l})\end{array}$ \\
\hline 1 & 100 & 100 & 50 & 49 \\
\hline 2 & 100 & 99 & 50 & 50 \\
\hline 3 & 100 & 100 & 50 & 49 \\
\hline 4 & 100 & 98 & 50 & 48 \\
\hline 5 & 100 & 99 & 50 & 49 \\
\hline
\end{tabular}

Pengujian pemilihan kode ' 7 ' dilakukan dengan cara menekan tombol inputan '7' pada keypad. Setelah tombol ditekan, solenoid valve akan membuka katup sehingga jamu kunyit asam pada botol 2 dan jamu pahitan pada botol 3 mengalir, selanjutnya jamu yang mengalir akan dihitung volumenya oleh sensor water flow. Dan pengujian pemilihan kode ' 7 ' dapat mengeluarkan jamu kunyit asam dan pahitan dengan jumlah volume antara $146-150 \mathrm{~mL}$.

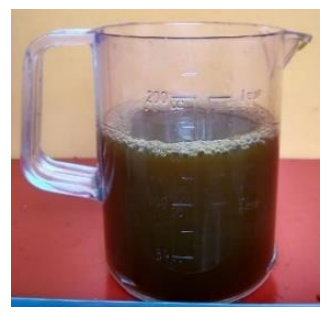

Gambar 21. Jamu Hasil Pengujian Pemilihan Kode '7'

Pemilihan Kode '8', untuk Jamu Kunyit Asam dan pahitan Pengujian pemilihan menu dengan kode ' 8 ' dapat ditunjukkan pada tabel berikut.

Tabel 14. Pengujian Pemilihan Kode ' 8 '

\begin{tabular}{|c|c|c|c|c||}
\hline \multirow{2}{*}{$\begin{array}{c}\text { Percobaan } \\
\text { ke- }\end{array}$} & \multicolumn{2}{|c|}{ Jamu Beras Kencur } & \multicolumn{2}{c|}{ Jamu Pahitan } \\
\cline { 2 - 5 } & $\begin{array}{c}\text { Volume } \\
\text { Mutlak (ml) }\end{array}$ & $\begin{array}{c}\text { Volume pada } \\
\text { Gelas Ukur (ml) }\end{array}$ & $\begin{array}{c}\text { Volume } \\
\text { Mutlak } \\
(\mathbf{m l})\end{array}$ & $\begin{array}{c}\text { Volume pada } \\
\text { Gelas Ukur } \\
(\mathbf{m l})\end{array}$ \\
\hline 1 & 100 & 99 & 50 & 49 \\
\hline 2 & 100 & 100 & 50 & 48 \\
\hline 3 & 100 & 100 & 50 & 50 \\
\hline 4 & 100 & 99 & 50 & 49 \\
\hline 5 & 100 & 99 & 50 & 48 \\
\hline
\end{tabular}

Pengujian pemilihan kode ' 8 ' dilakukan dengan cara menekan tombol inputan '8' pada keypad. Setelah tombol ditekan, solenoid valve akan membuka katup sehingga jamu kunyit asam pada botol 2 dan jamu gula jahe pada botol 4 mengalir, selanjutnya jamu yang mengalir akan dihitung volumenya oleh sensor water flow. Dan pengujian pemilihan kode ' 8 ' dapat mengeluarkan jamu kunyit asam dan pahitan dengan jumlah volume antara 148 - 150 $\mathrm{mL}$.

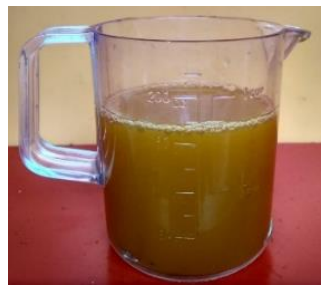

Gambar 22. Jamu Hasil Pengujian Pemilihan Kode '8' 


\section{KESIMPULAN}

Berdasarkan perancangan, implementasi dan pengujian yang telah dilakukan maka dapat diambil kesimpulan sebagai berikut.

1. Gelas dikatakan terdeteksi oleh sensor LDR jika nilai resistansi yang dibaca oleh sensor LDR adalah besar dari $500 \mathrm{ohm}$ (> 500) dan ketika motor DC dapat menggerakkan pengaduk, serta LCD dapat menampilkan tulisan "Kedai Jamu".

2. Pemilihan menu dapat dilakukan dengan inputan dari keypad berdasarkan kode menu yang ditawarkan dari kode '1' sampai kode '8', namun saat kode '9', ‘*', '0','\#' yang dipilih akan ditampilkan pada LCD bahwa menu tidak tersedia.

3. Nilai faktor pengali (kalibrasi) yang digunakan pada sensor water flow untuk volume $150 \mathrm{ml}$ yaitu 3.7 , untuk volume $100 \mathrm{ml}$ yaitu 2.7 , dan untuk $50 \mathrm{ml}$ yaitu 1.2 yang didapatkan dari nilai selisih terkecil antara volume mutlak dengan volume yang dibaca sensor menggunakan gelas ukur.

4. Rancang bangun sistem pencampur jamu yang dibuat dan telah diujikan masih ada kekurangan dari segi fungsionalitasnya, terutama adanya jamu yang tersendat pada pipa saat mengalir ke gelas.

\section{REFERENSI}

[1] Hanum, Musyri'ah. 2011. Pengobatan Tradisional dengan Jamu Ala Kraton Sebagai Warisan Turun Temurun. Yogyakarta : Andi Offset

[2] Yenni, Helda, M.Ridwan. 2015. Implementasi Kendali Mikrokontroler ATMega8535 pada Alat Pembuat Kopi Otomatis. Jurnal Edukasi dan Penelitian Informatika (JEPIN) Vol. 1, (2).

[3] Andrian, Heri, A.Darmawan. 2016. Arduino Belajar Cepat dan Pemrograman. Bandung : Informatika

[4] Zaini, E.Irhamdi. 2015. Perancangan Sistem Otomatisasi Gedung dengan Arduino dan Raspberry Pi. Padang : Andalas University Press

[5] Istiyanto, Jozi Eko. 2014. Pengantar Elektronika dan Implementasi Pendekatan Project Arduino dan Android. Yogyakarta : Andi Offset

[6] Tanpa Nama. Tanpa Tahun. Arduino Mega. Diakses melalui https://www.arduino.cc/en/Main/arduinoBoardMega/ , tanggal 8 Maret 2018

[7] Safaat H, Nazruddin. 2011. Android Pemrograman Aplikasi Mobile Smartphone dan Tablet PC Berbasis Android. Bandung : Informatika

[8] Siregar, KTT , Takdir T, Bisma P. 2013. Viskosimeter Digital Menggunakan Water Flow Sensor G1/2 Berbasis Mikrokontroller 8535. JSF Vol 4, (1)

[9 Hersyah, M. (2017, March 20). Identifikasi Rancang Bangun Alat Ukur dan Sistem Kendali Kadar Total Dissolved Solid (TDS) Pada Air Berbasis Mikrokontroller. Journal of Information Technology and Computer Engineering, 1(01), 26-34.

[10] Parallax Inc. Tanpa Tahun. PCB Relay G2RL. Diakses https://www.parallax.com/sites/default/files/downloads/40 0-00052-Omron-12V-Relay-Datasheet.pdf ， tanggal 14 Maret 2018
[11] Ihsanto, Eko , I.Buchori. 2017. Disain dan Implementasi Sistem Monitoring Pengisian Cairan Melalui Wifi dan Web. Jurnal Sinergi Vol.21 (1)

[12] Winarto, Tim Lentera. 2004. Khasiat dan Manfaat Kunyit. Jakarta : Agromedia Pustaka

[13] Wulandari, Rahmi Ayu , R.Azrianingsih. 2014. Etnobotani Jamu Gendong Berdasarkan Persepsi Produsen Jamu Gendong di Desa Karangrejo, Kecamatan Kromengan, Kabupaten Malang. Jurnal Biotropika Vol.2 (4)

[14] Koswara,Sutrisno. 2006. Jahe, Rimpang dengan Sejuta Khasiat. Jakarta : Pustaka Sinar Harapan

[15] Satria, Dedi , Yeni.Y, Maulinda. 2017. Rancang Bangun Sistem Penjadwalan Bel Sekolah Berbasis Arduino Uno dengan Antarmuka Berbasis Web Menggunakan Ethernet Web Server. Jurnal Serambi Engineering Vol.2 (3)

[16] Badidi, J., Asri, E., \& Aisuwarya, R. (2018, March 29). Rancang Bangun Robot Tank Automatik Pendeteksi Halangan dengan Kendali Fuzzy Logic. Journal of Information Technology and Computer Engineering, 2(01), 7-18.

[17] Pramujianto, MA. 2010. Aplikasi Mikrokontroler ATMega85335 Untuk Otomatisasi Pompa Motor DC dan Solenoid Valve pada Alat Ukur Tekanan Darah dan Denyut Nadi Gluterma Meter Digital. Diakses melalui http://eprints.undip.ac.id/20853/1/jurnalQ_arief.pdf tanggal 17 April 2018

[18] Amazon.com Inc. Tanpa Tahun. VEEROBOT 5V Hobby DC Motor. Diakses melalui https://www.amazon.in/VEEROBOT-5V-HobbyMotorLeads/, tanggal 17 April 2018 